\title{
The Antihyperlipidemic Effect of Lion's Mane Mushroom (Hericium erinaceus) in Hyperlipidemic Rats Induced by High Fat and Cholesterol Diet
}

\author{
Hyung Seok Jang, Ki Nam Yoon
}

Department of Clinical Laboratory Science, Ansan University, Ansan, Korea

\section{고지방과 콜레스테롤 식이로 유도된 고지혈증 흰쥐에서 노루궁뎅이버섯의 항고지혈증 효과}

\author{
장형석, 윤기남 \\ 안산대학교 임상병리과
}

\begin{abstract}
This study was conducted to investigate the dietary supplementation of fruiting body of Hericium erinaceus (HE) mushroom on lipid profiles of serum and histological changes of the liver in rats with high fat and cholesterol diet. Five-week old female Sprague-Dawley albino rats were divided into three groups of 8 rats each: The normal control diet (NC group), high fat and cholesterol diet (HFC group), and HFC diet supplemented with $5 \%$ fruiting powder of Hericium erinaceus (HFC+HE group). In the HFC+HE group, serum total cholesterol, low density lipoprotein, and triglyceride concentrations were significantly reduced compared with the NC group. Body weight gain of those in the HFC+HE group were lower than those in the HFC group; whereas HFC+HE had no effect on the levels of plasma albumin, creatinine, blood urea nitrogen, uric acid, glucose, and total protein. The enzyme activities related to the liver function, such as aspartate aminotransferase (AST), alanine aminotransferase (ALT), and, alkaline phosphatase (ALP), were lower in the NC group than in the HFC group, but without significance. Feeding the mushroom increased the excretion of total lipid and cholesterol. A histopathological analysis showed that the those in the HFC group developed hepatic steatosis, whereas those in the HFC+HE group developed small fat droplet. In conclusion, these results suggest that $5 \% \mathrm{HE}$ supplementation to HFC diet provided health benefits by acting on lowering atherogenic lipid profile in rats with high fat and cholesterol diet.
\end{abstract}

Key words: Antihyperlipidemia, Biochemical parameters, Hericium erinaceus mushroom, Histopathology

This is an Open Access article distributed under the terms of the Creative Commons Attribution Non-Commercial License (http://creativecommons.org/licenses/by-nc/4.0) which permits unrestricted non-commercial use, distribution, and reproduction in any medium, provided the original work is properly cited.

Copyright (C 2017 The Korean Society for Clinical Laboratory Science. All rights reserved.
Corresponding author: Hyung Seok Jang Department of Clinical Laboratory Science, Ansan University, 155 Ansandaehak-ro,

Sangnok-gu, Ansan 15328, Korea

Tel: 82-31-400-6935

Fax: 82-31-363-7702

E-mail: himylife@ansan.ac.kr

Received: July 31, 2017

Revised $1^{\text {st: }}$ August 11, 2017

Revised $2^{\text {nd }}$ : August 11, 2017

Revised $3^{\text {rd: }}$ : August 14, 2017

Accepted: August 14, 2017

\section{서 론}

현대사회는 생활환경이 편리해지고 과학과 의학의 발달로 인하여 과거에 비하여 매우 풍족한 생활을 누리게 되었지만, 식 사의 패턴이 식물성과 당질 위주의 식품에서 육류 및 가공식품
등 지방 함량이 높은 식품의 섭취 증가로 인해 고지혈증과 같은 심혈관계 질환의 발생이 늘어나면서 심각한 사회적 문제로 대 두되고 있다[1]. 심혈관계 질환이 발생하는 원인에는 여러 요인 들이 관여하고 있으나 혈청의 총콜레스테롤, 저밀도지단백질 (LDL-cholesterol) 및 중성지방이 증가하여 나타나는 고지혈 
증이 주요 인자로 알려져 있다[2]. 고콜레스테롤 혈증에는 콜레 스테롤 및 중성지방 식품의 섭취가 밀접하게 관련되어 있으며 특히 동물성 포화지방의 과다 섭취는 혈청의 총콜레스테롤의 농도를 높여 심혈관계 질환을 비롯한 여러 가지 질병을 발생시 키는 요인이 된다고 보고되어 있다[3]. 이제까지 고지혈증을 치 료하기 위해 많은 시도가 이루어져 효과가 높은 새로운 의약품 이 개발되었으나 장기 복용에 따른 부작용의 위험성으로 인해 고지혈증에 개선에 효과가 높고 부작용이 적은 천연물을 이용 한 식이요법을 선호하는 경향이 늘어나고 있다[4].

버섯은 단백질, 지방, 탄수화물, 비타민, 무기염류 등이 골고 루 함유되어 있고, 독특한향과맛을 갖고 있어 기호성이 높은 식 품일 뿐 아니라, 면역증강. 항암활성, 혈압강하, 항산화, 소염활 성, 항균작용 등의 약리효과가 밝혀지면서 건강 기능식품과 의 약품의 소재로 이용이 확대되고 있다 $[5,6,7,8]$. 노루궁뎅이버섯 (Hericium erinaceus)은 담자균문의 무당버섯목(Russulales), 산호침버섯과(Hericiaceae), 산호침버섯속에 속하는 버섯으로 가을철 활엽수의 고목이나 생목에 발생하며 중국에서는 원숭이 머리버섯, 사자머리버섯으로 알려져 있으며, 일본에서는 Yamabushitake, 우리나라에서는 노루궁뎅이버섯으로 부르고 있다 [9,10]. 노루궁뎅이버섯에는 다양한 영양소가 풍부하게 함유되 어있으며 항염, 항암 및 면역 기능을 증대시키는 물질이 함유되 어 있다고 보고되어 있으며[11-13] 또한 치매를 일으키는 원인 의 하나인 기억력의 감퇴를 지연시키는 물질이 보고되는 등 인 체의 건강에 도움이 되는 다양한 물질이 함유되어 있는 것으로 보고되었다[14].

따라서 본 연구에서는 우리나라에서 재배되는 노루궁뎅이버 섯이 동물성지방의 과다 섭취에 의해 발생하는 비만이나 심혈 관계 질환에 미치는 효과를 알아보고자 생후 5주 령의 Sprague Dawley (SD)계 암컷 흰쥐를 대상으로 정상식이(NC), 고지방 콜레스테롤 식이(HFC, 돈지 10\%와 콜레스테롤 $1 \%$ 첨가 식이), 그리고 고지방 - 콜레스테롤 식이에 노루궁뎅이버섯 자실체 분 말을 $5 \%$ 수준으로 첨가한 식이 $(\mathrm{HFC}+\mathrm{HE})$ 를 흰쥐에 6주간 급여 하여 노루궁뎅이버섯을 첨가한 식이의 급여가 실험동물의 체중 증가, 혈청의 콜레스테롤, 중성지질, 고밀도지단백질(HDL-C), 저밀도지단백질(LDL-C)의 농도 및 동맥경화지수(AI) 등에 미 치는 효과와 혈청의 당 농도, 단백질 농도 그리고 간질환과 관련 이 있는 효소의 활성에 미치는 영향에 대해서 조사하였다. 또한 노루궁뎅이버섯 첨가 식이 급여가 흰쥐의 간 조직의 구조에 미 치는 효과에 대해서도 현미경 검경을 통해 조사하였다.

\section{재료 및 방법}

\section{1. 실험동물}

실험동물은 4주령의 Sprague Dawley계 흰쥐 암컷을 Daehan Bio Link사(Eumseong, Korea)에서 분양받아 사육용 케이지에서 1주일간 일반사료로 적응 시킨 후 난괴법(randomized complete block design)으로 각 처리 군당 8마리씩 3 그룹으로 나누었다. 실험에 사용한 식이는 대조군(normal control diet, NC), 고지방 · 콜레스테롤 식이군(high fat and cholesterol diet, $\mathrm{HFC}$ ), 고지방 - 콜레스테롤 식이에 노루궁뎅 이버섯 자실체 분말을 $5 \%$ 첨가한 군 $(\mathrm{HFC}+\mathrm{HE})$ 으로 나누어 6주 간 사육하였다. 사육 기간 동안 사육실의 온도는 $22 \pm 2^{\circ} \mathrm{C}$, 습도 는 50 55\%로 유지하였고 12시간 주기로 명암(07:00 19:00)을 자동 조절하였으며, 물과 사료는 자유 급식하였다. 사 료섭취량과 체중은 매주 1 회 측정하여 식이 효율을 분석하였다. 모든 실험은 안산대학교 동물실험윤리위원회 규정에 입각하여 수행하였다.

\section{2. 버섯 분말의 제조}

본 실험에 사용한 노루궁뎅이버섯의 자실체는 경기도농업기 술원 버섯연구소에서 제공받아 $50^{\circ} \mathrm{C}$ 의 온풍 건조기에서 48 시 간 건조하여 분말화한 후실험 시료로 사용하였다. 시료는 $-20^{\circ} \mathrm{C}$ 에서 냉동 보관하면서 실험에 사용하였다.

\section{3. 식이 제조}

본 실험의 기본 식이 조성은 AIN-93에 따라 제조하였다[15]. 고지방식이는 기본식이에 각각 $1 \%$ 의 콜레스테롤과 $15 \%$ 의 돈 지(lard)를 첨가하여 제조하였으며, 버섯자실체 분말 첨가 식이 는 Alam 등[16]의 연구 보고를 참고하여 고지방 · 콜레스테롤 식이에 $5 \%$ 수준의 노루궁뎅이버섯의 자실체 분말을 첨가하여 pellet 형태의 사료로 제조한 후 실험동물에 급여하였다. 실험 에 사용한 3 종 식이의 구성 성분은 Table 1과 같다.

\section{4. 혈청의 분리 및 생화학적 분석}

실험 사육 6주간 후 흰쥐를 14 시간 동안 절식시킨 뒤 $\mathrm{CO}_{2}$ 가 스로 마취하여 심장 채혈하고, $3,500 \mathrm{rpm}$ 에서 15 분간 $4^{\circ} \mathrm{C}$ 에서 원심분리 하여 혈청을 분리한 뒤 $-80^{\circ} \mathrm{C}$ 에 냉동 보관하여 분석 에 사용하였다. 혈청의 cholesterol (TC), high density lipoprotein cholesterol (HDL-C), low density lipoprotein cholesterol (LDL-C), triglyceride (TG), glucose, aspartate aminotransferase (AST), alanine aminotransferase (ALT), 
Table 1. Composition of the experimental diet

\begin{tabular}{lccc}
\hline \multicolumn{1}{c}{ Ingradient } & NC & HFC & HFC+HE \\
\hline Corn starch & 550 & 390 & 385 \\
Casein & 200 & 200 & 200 \\
L-Cystine & 3 & 3 & 3 \\
Sucrose & 100 & 100 & 100 \\
Cellulose & 50 & 50 & 50 \\
Soybean oil & 50 & 50 & 50 \\
Lard & 0 & 150 & 150 \\
Vitamin mixture & 10 & 10 & 10 \\
Mineral mixture & 35 & 35 & 35 \\
Choline bitartrate & 2.0 & 2.0 & 2.0 \\
Cholesterol & - & 10 & 10 \\
Mushroom powder & - & - & 50 \\
Total & 1,000 & 1,000 & 1,000 \\
\hline
\end{tabular}

Abbreviation: NC, normal control diet; HFC, high fat and cholesterol diet; $\mathrm{HFC}+\mathrm{HE}$, high fat and cholesterol diet $+5 \%$ Hericium erinaceus fruiting body powder.

Mineral mixture; AIN-93 mineral mixture [15].

Vitamin mixture; AIN-93 vitamin mixture [15].

and ,alkaline phosphatase (ALP), alkaline phosphatase (ALP), total protein, albumin, blood urea nitrogen, creatinine, uric acid의 농도는 Hitachi 7180 자동생화학분석기(Hitachi, Tokyo, Japan)에 Sekisui 사(Sekisui, Tokyo, Japan)의 시약을 사용하여 측정하였다. 동맥경화지수(atherogenic index: AI) 는 Haglund 등[17]의 방법에 따라 $\mathrm{AI}=($ total cholesterolHDL-cholesterol)/HDL-cholesterol 식을 이용해 구하였다.

\section{5. 간의 조직학적 분석}

적출한 간조직을 $-70^{\circ} \mathrm{C}$ 에서 동결한 후 동결 절편기를 사용 하여 $5 \mu \mathrm{m}$ 의 두께로 박절한 후 gelatin 으로 표면 처리된 슬라이 드에 부착시켰다. 이 슬라이드에 PBS 용액을 가한 다음 무수 propylene glycol 용액에 2 분간 헹군 후 $0.5 \%$ oil red $\mathrm{O}$ 용액에 1 시간 동안 염색하였다. 이 후 $85 \%$ propylene glycol 용액에 1 분간 감별시키고 증류수로 두 번 세척한 후 polymount로 봉입 하여 광학현미경상에서 $\mathrm{X} 100$ 과 $\mathrm{X} 400$ 의 배율로 관찰하였다 [18].

\section{6. 변의 총지방과 콜레스테롤 양의 측정}

식이를 섭취한 35 일과 42 일 사이 실험동물의 변을 받아 지방 과 콜레스테롤의 양을 측정하였다. 변 지방은 Folch 등[19]의 방법을 변형하여 측정하였다. 건조한 변 분말 $1 \mathrm{~g}$ 을 chloroform:methanol (2:1) 용액 $20 \mathrm{~mL}$ 을 넣어 $25^{\circ} \mathrm{C}$ 에서 3 시간 동 안 shaking한 후 1차 여과하였다. 다시 chloroform $15 \mathrm{~mL}$ 을 넣어 동일 조건에서 overnight shaking하여 지방을 추출한 후 여과하여 1차 여과액과 합하여 농축한 후 총지방의 함량을 측정
Table 2. Effect of Hericium erinaceus mushroom on body weight and food intakes of rats

\begin{tabular}{lccc}
\hline \multicolumn{1}{c}{ Parameters } & $\mathrm{NC}$ & $\mathrm{HFC}$ & $\mathrm{HFC}+\mathrm{HE}$ \\
\hline Initial body weight $(\mathrm{g})$ & $102.4 \pm 4.6$ & $101.6 \pm 5.2$ & $102.5 \pm 3.2$ \\
Final body weight $(\mathrm{g})$ & $243.9 \pm 4.7$ & $254.7 \pm 4.8$ & $239.0 \pm 4.4$ \\
$\begin{array}{l}\text { Weight gain } \\
\text { (g/6 weeks) }\end{array}$ & $141.4 \pm 3.5$ & $153.1 \pm 3.3$ & $136.5 \pm 2.8$ \\
$\begin{array}{c}\text { Total food intake } \\
\text { (g/6 weeks) }\end{array}$ & $741.3 \pm 7.6$ & $672.3 \pm 7.5$ & $644.1 \pm 5.4$ \\
FER & $0.19 \pm 0.01$ & $0.23 \pm 0.02$ & $0.20 \pm 0.01$ \\
\hline
\end{tabular}

Abbreviation: FER (Food efficiency ratio)=body weight gain for experimental period/Food intake for experimental period.

The values are mean $\pm \mathrm{SD}(\mathrm{N}=8)$.

Different letters in the same row indicate significant differences among groups at $p<0.05$ as determined by Duncan's multiple range tests.

하였다. 콜레스테롤은 위와 동일한 방법으로 추출한 후 cholesterol oxidase kit (Asan Pharmaceutical, Seoul, Korea)를 이 용하여 함량을 측정하였다.

\section{7. 통계처리}

본 연구에서는 3 회 이상 반복 실시한 결과를 mean $\pm \mathrm{SD}$ 로 나 타내었으며, 통계는 SPSS ver. 11.5 (SPSS, Chicago, IL, USA) 를 이용하였다. 각 군 간의 측정치 비교는 one-way analysis of variance (ANOVA) test를 실시한 후 $p<0.05$ 의 유의수준에서 Duncan's multiple range test로 차이를 검증하였다.

\section{결 과}

\section{1. 체중, 식이섭취량 및 식이효율}

정상식이 $(\mathrm{NC})$, 고지방 • 콜레스테롤식이 $(\mathrm{HFC})$, 고지방 • 콜 레스테롤식이에 노루궁뎅이버섯 자실체 분말을 $5 \%$ 수준으로 첨가한 식이 $(\mathrm{HFC}+\mathrm{HE})$ 를 42 일간 급여한 흰쥐의 체중 변화, 식 이섭취량 및 식이 효율을 Table 2에 나타내었다. HFC군의 평균 체중의 증가량은 $153.1 \mathrm{~g}$ 으로 $\mathrm{NC}$ 군의 $141.4 \mathrm{~g}$ 에 비해 $27.4 \%$ 증가해서 유의하였으며 $(p<0.05) \mathrm{HCF}+\mathrm{HE}$ 군의 체중은 136.5 $\mathrm{g}$ 으로 정상식이군에 비해 낮았으나 유의성은 없었다. 실험기간 중 식이섭취량은 개체 당 $\mathrm{NC}$ 군이 가장 많은 $669.3 \mathrm{~g}$ 을 섭취하 였고, 다음으로 $\mathrm{HFC}$ 군이 $651.4 \mathrm{~g}$ 을 섭취하였으며, $\mathrm{HFC}+\mathrm{HE}$ 군 이 가장 적은 $536.1 \mathrm{~g}$ 의 식이를 섭취하였으나 $\mathrm{HFC}$ 군과 $\mathrm{HFC}+\mathrm{HE}$ 군의 식이섭취량은 $\mathrm{NC}$ 군에 비해 낮은 유의성을 보였다 $(p<0.05)$. 실험기간 중 각각의 처리군의 식이효율성은 $\mathrm{HFC}$ 군(0.23)이 $\mathrm{NC}$ 군(0.19)이나 $\mathrm{HFC}+\mathrm{HE}$ 군(0.20)에 비해 높은 유의성을 보였 다 $(p<0.05)$. 


\section{2. 혈청의 지질농도 분석}

정상 식이, 고지방 식이, 고지방 식이에 $5 \%$ 의 노루궁뎅이버 섯 자실체 분말을 첨가한 식이를 6주간 급여한 흰쥐의 혈청 지 질을 분석하여 그 결과를 Table 3에 나타내었다. 혈청의 총콜레 스테롤 농도는 $\mathrm{NC}$ 군과 $\mathrm{HFC}+\mathrm{HE}$ 군이 각각 $95.5 \mathrm{mg} / \mathrm{dL}$ 과 $80.25 \mathrm{mg} / \mathrm{dL}$ 로 $\mathrm{HFC}$ 군의 $115.5 \mathrm{mg} / \mathrm{dL}$ 에 비해 각각 $20.9 \%$ 와 $43.9 \%$ 낮아 통계적으로 유의한 결과를 나타냈다 $(p<0.05)$. 혈 청의 $\mathrm{HDL}$-콜레스테롤의 농도는 $\mathrm{NC}$ 군, $\mathrm{HFC}$ 군 및 $\mathrm{HFC}+\mathrm{HE}$ 군 이 각각 $40.13 \mathrm{mg} / \mathrm{dL}, 44.38 \mathrm{mg} / \mathrm{dL}, 38.5 \mathrm{mg} / \mathrm{dL}$ 을 나타내 각 실험군간 통계적인 유의성은 보이지 않았다. LDL-콜레스테롤 농도는 $\mathrm{NC}$ 군이 $10.43 \mathrm{mg} / \mathrm{dL}, \mathrm{HFC}+\mathrm{HE}$ 군이 $7.88 \mathrm{mg} / \mathrm{dL}$, $\mathrm{HFC}$ 군이 $19 \mathrm{mg} / \mathrm{dL}$ 로 측정되어 $\mathrm{HFC}$ 군에 비해 $\mathrm{NC}$ 군과 $\mathrm{HFC}+\mathrm{HE}$ 군의 LDL-콜레스테롤 농도가 각각 $82.2 \%$ 와 $141.1 \%$ 감소되어 $\mathrm{HFC}$ 군과 비해 유의 $(p<0.05)$ 하였으나 $\mathrm{NC}$ 군과 $\mathrm{HFC}+\mathrm{HE}$ 군 간의 LDL-콜레스테롤의 농도에 유의성은 없었다. 혈청의 중성지방 농도는 $\mathrm{HFC}+\mathrm{HE}$ 군 $(40.88 \mathrm{mg} / \mathrm{dL})$ 이 $\mathrm{NC}$ 군 $(62.13 \mathrm{mg} / \mathrm{dL})$ 과 $\mathrm{HFC}$ 군 $(85.25 \mathrm{mg} / \mathrm{dL})$ 에 비해 각각 $52 \%$ 와 $100.5 \%$ 낮아 $\mathrm{NC}$ 군에 비해 유의 $(p<0.05)$ 하였고, $\mathrm{HFC}$ 군에 비 해서는 고도의 유의성을 보였다 $(p<0.01)$. 동맥경화지수(AI)는 $\mathrm{NC}$ 군이 1.38, $\mathrm{HFC}$ 군이 1.6, $\mathrm{HFC}+\mathrm{HE}$ 군이 1.08을 나타내

Table 3. The lipid profiles in plasma of rats fed with Hericium erinaceus mushroom

\begin{tabular}{cccc}
\hline $\begin{array}{c}\text { Parameters } \\
(\mathrm{mg} / \mathrm{dL})\end{array}$ & $\mathrm{NC}$ & $\mathrm{HFC}$ & $\mathrm{HFC}+\mathrm{HE}$ \\
\hline $\mathrm{TC}$ & $95.50 \pm 3.12$ & $115.50 \pm 3.43$ & $80.25 \pm 2.82$ \\
$\mathrm{HDL}-\mathrm{C}$ & $40.13 \pm 2.52$ & $44.38 \pm 3.81$ & $38.50 \pm 2.50$ \\
$\mathrm{LDL}-\mathrm{C}$ & $10.43 \pm 0.97$ & $19.00 \pm 1.22$ & $7.88 \pm 1.09$ \\
$\mathrm{TG}$ & $62.13 \pm 4.14$ & $85.25 \pm 4.84$ & $40.88 \pm 2.47$ \\
$\mathrm{Al}$ & $1.38 \pm 0.23$ & $1.60 \pm 0.29$ & $1.08 \pm 0.15$ \\
\hline
\end{tabular}

Abbreviation: TC, total cholesterol; $\mathrm{HDL}-\mathrm{C}$, high-density lipoprotein cholesterol; LDL-C, low-density lipoprotein cholesterol; TG, triglycerides; Al, (atherogenic index) $=[$ (total cholesterol-HDL-cholesterol)]/HDL-cholesterol.

Table 4. Effect of Hericium erinaceus mushroom on biochemical parameters in rats

\begin{tabular}{lccc}
\hline \multicolumn{1}{c}{ Parameters } & $\mathrm{NC}$ & $\mathrm{HFC}$ & $\mathrm{HFC}+\mathrm{HE}$ \\
\hline Albumin $(\mathrm{g} / \mathrm{dL})$ & $3.01 \pm 0.15$ & $3.11 \pm 0.18$ & $2.74 \pm 0.16$ \\
Creatinine $(\mathrm{g} / \mathrm{dL})$ & $0.58 \pm 0.04$ & $0.59 \pm 0.02$ & $0.56 \pm 0.03$ \\
Blood urea nitrogen & $17.63 \pm 0.47$ & $18.14 \pm 0.72$ & $17.50 \pm 0.87$ \\
$\quad(\mathrm{~g} / \mathrm{dL})$ & & & \\
Uric acid $(\mathrm{g} / \mathrm{dL})$ & $2.03 \pm 0.16$ & $2.38 \pm 0.18$ & $1.86 \pm 0.93$ \\
Glucose $(\mathrm{g} / \mathrm{dL})$ & $127.25 \pm 6.09$ & $138.50 \pm 4.95$ & $124.63 \pm 4.09$ \\
Total protein $(\mathrm{g} / \mathrm{dL})$ & $6.91 \pm 0.18$ & $7.15 \pm 0.21$ & $6.71 \pm 0.23$ \\
\hline
\end{tabular}

$\mathrm{HFC}+\mathrm{HE}$ 군의 동맥경화지수가 $\mathrm{NC}$ 군과 $\mathrm{HFC}$ 군에 비해 유의성 있게 낮았다 $(p<0.05)$.

\section{3. 혈청의 생화학적 지표의 분석}

정상 식이, 고지방 식이, 고지방 식이에 $5 \%$ 의 노루궁뎅이버 섯 자실체의 분말을 첨가한 식이를 각각 6주간 섭취한 흰쥐 혈 청의 알부민, 크레아티닌, 요산, 포도당, 총단백질 농도를 생화 학적으로 분석하여 Table 4 에 표시하였다. $\mathrm{HFC}+\mathrm{HE}$ 군의 혈청 알부민, 크레아티닌, 요산, 포도당, 총단백질의 농도는 $\mathrm{HFC}$ 군 에 비해서 각각 $11.9,5.1,21.8,10,6.2 \%$ 감소하여 통계적으로 유의성 있는 결과 $(p<0.05)$ 를 보였으나 $\mathrm{NC}$ 군에 비해 모든 생화 학적 지표는 유의성이 없었다.

\section{4. 혈청의 간세포관련 효소활성 분석}

정상 식이, 고지방 식이, 고지방 식이에 $5 \%$ 의 노루궁뎅이버 섯 자실체의 분말을 첨가한 식이를 각각 6주간 흰쥐에 섭취시킨 후 간에 미치는 영향을 조사하기 위해 간질환과 관련이 있는 효 소의 활성을 측정하여 Table 5에 표시하였다. 혈청의 aspartate aminotransferase (AST)의 활성은 $\mathrm{NC}$ 군, $\mathrm{HFC}$ 군, $\mathrm{HFC}+\mathrm{HE}$ 군 에서 각각 75.38, 82, 74.75 U/L을 나타냈고 alanine aminotransferase (ALT)의 활성은 각각 $50.5,57.13,51.5 \mathrm{U} / \mathrm{L}$, alkaline phosphatase (ALP)는 각각 299.13, 377, 290.05 U/L 의 활성을 나타냈다. $\mathrm{NC}$ 군, $\mathrm{HFC}$ 군 및 $\mathrm{HFC}+\mathrm{HE}$ 군의 $\mathrm{AST}, \mathrm{ALT}$ 및 $\mathrm{ALP}$ 효소의 활성은 $\mathrm{NC}$ 군과 $\mathrm{HFC}+\mathrm{HE}$ 군은 유사한 활성 수준 을 나타내 통계적으로 유의성은 없었으나 $\mathrm{HFC}$ 군에 비해 이들 효소의 활성은 유의한 결과를 나타냈다 $(p<0.05)$.

Table 5. Effect of Hericium erinaceus mushroom on plasma enzyme profiles related to liver function in rats

\begin{tabular}{cccc}
\hline $\begin{array}{c}\text { Parameters } \\
(\mathrm{U} / \mathrm{L})\end{array}$ & $\mathrm{NC}$ & $\mathrm{HFC}$ & $\mathrm{HFC}+\mathrm{HE}$ \\
\hline AST & $75.38 \pm 4.21$ & $82.00 \pm 3.16$ & $74.75 \pm 7.63$ \\
ALT & $55.50 \pm 3.12$ & $57.13 \pm 4.26$ & $51.50 \pm 2.40$ \\
ALP & $299.13 \pm 18.31$ & $377.00 \pm 25.91$ & $290.05 \pm 15.39$ \\
\hline
\end{tabular}

Abbreviation: AST, aspartate aminotransferase; ALT, alanine aminotransferase; ALP, alkaline phosphatase.

Table 6. Effects of Hericium erinaceus mushroom on fecal total lipid and cholesterol in rats

\begin{tabular}{cccc}
\hline $\begin{array}{c}\text { Parameters } \\
(\mathrm{mg} / 100 \mathrm{~g} \text { dry feces })\end{array}$ & NC & HFC & HFC+HE \\
\hline Total lipid & $18.3 \pm 0.3$ & $50.4 \pm 0.6$ & $61.1 \pm 1.3$ \\
Cholesterol & $3.4 \pm 0.2$ & $12.6 \pm 0.5$ & $13.1 \pm 0.3$ \\
\hline
\end{tabular}




\section{5. 변의 지질 및 콜레스테롤 배설효과}

정상 식이, 고지방 식이, 고지방 식이에 $5 \%$ 의 노루궁뎅이버 섯 자실체의 분말을 첨가한 식이를 각각 6주간 섭취한 흰쥐가 배출한 변의 지질과 콜레스테롤 양을 분석하여 그 결과를 Table 6 에 나타내었다. 변을 통해 배출된 총지질의 양은 $\mathrm{NC}$ 군, $\mathrm{HFC}$ 군, $\mathrm{HFC}+\mathrm{HE}$ 군이 각각 $18.3,50.4,61.1 \mathrm{mg} / 100 \mathrm{~g}$ 을 나타내어 $\mathrm{HFC}+\mathrm{HE}$ 군이 배출한 총지질의 양이 $\mathrm{NC}$ 군에 비해 고도로 유의 하게 높았고 $(p<0.01), \mathrm{HFC}$ 군에 비해서는 유의하게 높았다 $(p<0.05)$. 변을 통해 배출된 총콜레스테롤의 양도 $\mathrm{HFC}+\mathrm{HE}$ 군 $(13.1 \mathrm{mg} / 100 \mathrm{~g})$ 이 NC군(3.4 mg/100 g)에 비해 유의하게 높 았으나 $(p<0.05), \mathrm{HFC}$ 군 $(12.6 \mathrm{mg} / 100 \mathrm{~g})$ 에 비해서는 통계적 으로 유의성을 나타내지 않았다.

\section{6. 간의 조직학적 검사}

정상 식이, 고지방 식이, 고지방 식이에 $5 \%$ 의 노루궁뎅이버 섯 자실체의 분말을 첨가한 식이를 각각 6주간 흰쥐에 섭취시킨 후 간에 미치는 병리조직학적 효과를 조사하였다(Figure 1). 적 출한 간을 oil red O로 염색하여 현미경을 이용해 $\times 100$ 과 $\times 400$ 배율로 관찰한 결과 $\mathrm{NC}$ 군의 경우 세포질 위축이나 지방 질 소견이 발견되지 않았으나, $\mathrm{HFC}$ 군의 경우 $\mathrm{NC}$ 군에 비해 세 포사이에 다량의 지방질축적이 관찰되었고, $\mathrm{HFC}+\mathrm{HE}$ 군에서는 세포질 위축 등 비정상적인 소견은 보이지 않았으나 세포사이 에 소량의 지방질축적이 관찰되었다.

\section{고 찰}

본 실험 결과, 6 주간 고지방 - 콜레스테롤 식이에 노루궁뎅이 버섯의 자실체 분말을 $5 \%$ 첨가하여 급여한 $\mathrm{HFC}+\mathrm{HE}$ 군의 체중 이 $\mathrm{HFC}$ 군에 비해 유의성 있게 감소하는 효과가 나타났으며, 정 상식이(NC)군과는 통계적인 유의성이 없었다. Oh 등[20]은 고 지방식이에 신령버섯 자실체 분말을 $5 \%$ 수준으로 첨가하여 급 여한 흰쥐 실험군의 체중이 고지방식이에 비해 유의성 있게 감 소하였으나 정상식이를 급여한 군에 비해 체중증가율은 통계적 으로 유의하지 않았다고 보고하였다. Koh와 Choi [21]는 $1 \%$ 의 콜레스테롤 식이에 동충하초 자실체 분말을 $3 \%$ 첨가한 실험군 의 체중증가율이 콜레스테롤 식이군에 비해 유의하게 낮아 동 충하초의 자실체 분말 급여는 흰쥐의 체중 증가를 억제하는 효 과가 있다고 보고하였다. Park 등[22]은 버섯의 자실체와 곡물 에 함유되어 있는 $\beta$-glucan이 위의 포만감을 유지하고, 장관 내 의 점성을 증가하고 지방의 흡수를 지연시켜 흰쥐의 체중 증가 를 감소시키는 효과가 있다고 보고하였다. Bisen 등[23]은 고지 방 식이에 표고버섯 분말을 $5 \%$ 첨가하여 흰쥐에 급여했을 때 체 중이 유의하게 감소하였는데 그 원인이 표고버섯 자실체에 다 량으로 함유되어 있는 섬유소와 $\beta$-glucan이 사료의 지방성분 을 장에서 효과적으로 흡착해 분변으로 배출한 것에 기인한다 고 보고하였다. 따라서 본 실험에서도 위의 연구 결과와 유사하 게 노루궁뎅이버섯의 자실체에 함유된 다당류, 섬유소 및 기타 성분에 의해 흰쥐의 체증 증가와 식이 효율성이 감소해 정상 식
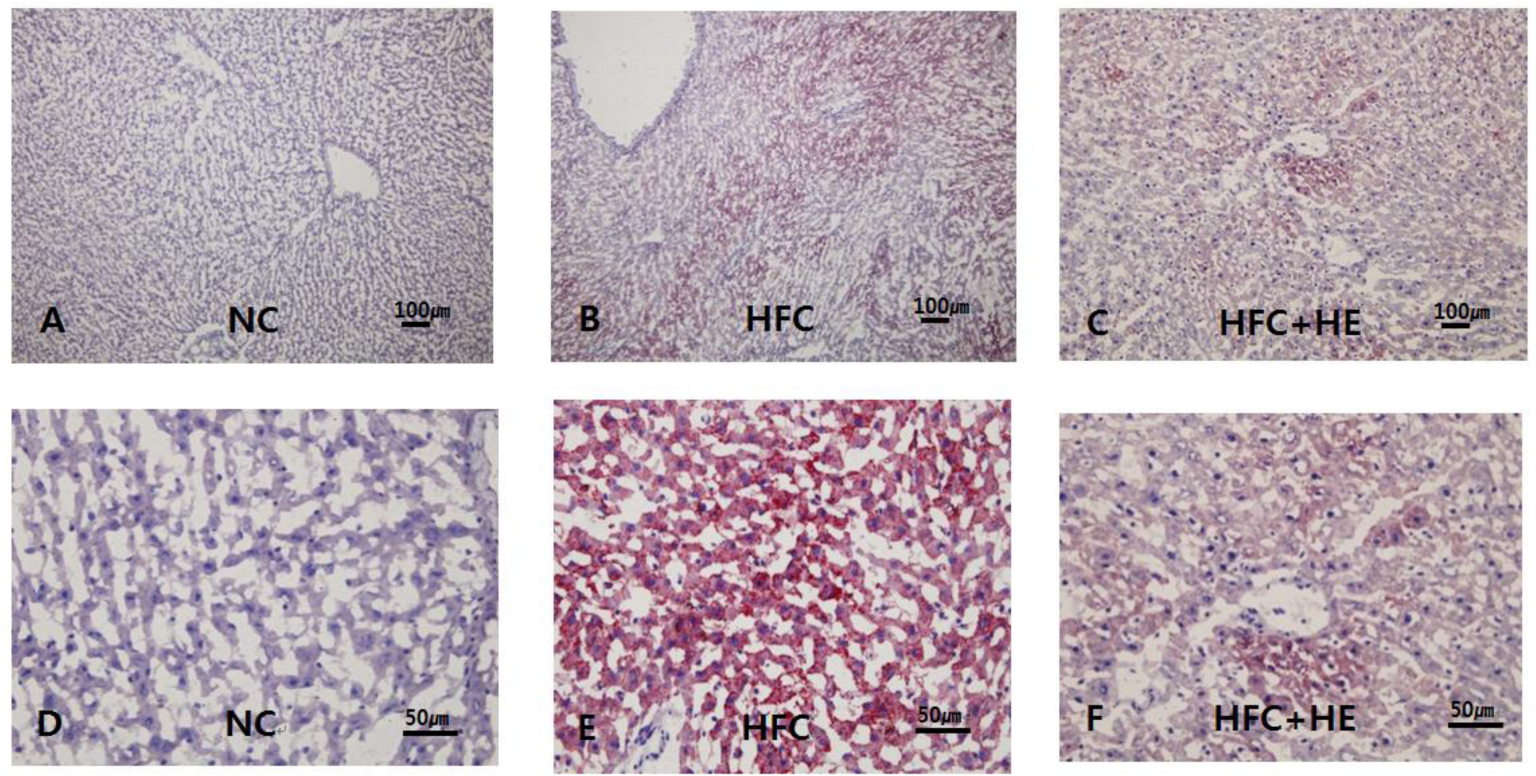

Figure 1. Effect of feeding Hericium erinaceus mushroom on hepatocyte cells in rats. $(A \sim C)$, oil red $O$ stained photomicrographs at $\times 100$; $(D \sim F)$, photomicrographs of red $O$ stain at $\times 400$. 
이군에 비해 유의하지 않았으나 고지방 - 콜레스테롤군에 비해 서는 유의하게 낮았다.

혈액 내 지질은 콜레스테롤, 중성지방, 인지질, 자유지방산 등으로 구성되어 있고, 지질단백질의 형태로 혈관을 통해 순환 한다. 지질의 합성과 분해에 불균형이 생기면 생리적으로 여러 문제가 발생하기 때문에 혈중의 지질 농도를 적절히 관리하고 유지해야 고지혈증의 발생을 예방할 수 있는 것으로 보고되었 다[24]. 버섯의 콜레스테롤 저해효과에 대한 선행 연구 결과를 보면, 고지방식이에 동충하초의 자실체 분말을 $5 \%$ 수준으로 첨 가하여 사육한 흰쥐 혈청의 총콜레스테롤과 중성지방의 농도는 유의하게 감소했으며[25], 고지방 · 콜레스테롤 식이에 느타리 버섯의 분말을 첨가하여 Syrian hamster에 급여하였을 때 혈청 의 콜레스테롤 농도가 유의하게 감소했다는 보고도 있다[26]. 고지혈증을 유발한 흰쥐에 눈꽃동충하초의 자실체와 균사체 분 말을 각각 $3 \%$ 수준으로 첨가한 식이를 5주간 흰쥐에 급여한 결 과 중성지방, 총 콜레스테롤, LDL-콜레스테롤 및 동맥경화지수 가 유의하게 감소하여 정상 식이를 급여한 실험군과 유사한 효 과를 나타냈다고 하였다[27]. Cheung [28]은 정상 식이에 콜레 스테롤 1\% 첨가한 고콜레스테롤 식이에 흰목이버섯 분말을 $5 \%$ 첨가하여 흰쥐에 급여했을 때 혈청의 총콜레스테롤과 중성지방 이 유의하게 감소하였는데 이는 흰목이버섯에 함유된 $\beta$-glucan 이나 기타의 성분이 흰쥐의 콜레스테롤과 중성지방을 감소시킨 것이라고 하였다. 최근 연구에 의하면 혈중의 지질농도와 체중 은 상호 밀접하게 관련되어 있어서 총콜레스테롤, 중성지방 및 $\mathrm{LDL}$-콜레스테롤 수치가 증가하면 체중이 증가하고, 총콜레스 테롤과 중성지방의 수치가 감소하면, 체중이 감소한다고 보고 하였다[29].

본 실험에서 고지혈증을 유발할 수 있는 혈중 총 콜레스테롤, $\mathrm{LDL}$-콜레스테롤, 중성지방의 농도가 $\mathrm{HFC}$ 군에서 높게 측정되 었고 이에 반해 $\mathrm{HFC}+\mathrm{HE}$ 군의 지질 농도는 정상 식이를 급여한 $\mathrm{NC}$ 군과 유사하게 감소하여 $\mathrm{HFC}$ 군에 비해 유의하게 낮았다. 따 라서 노루궁뎅이버섯 자실체 분말을 첨가한 식이를 급여한 흰 쥐의 혈중 지질농도가 $\mathrm{NC}$ 군과 유사하게 현저히 감소한 것은 이 버섯에 함유된 유효 물질이 혈중 총지질의 함량을 감소시켜 고 지혈증 유발을 억제해 동맥경화지수나 비만을 개선했다고 사료 되나 혈중의 총콜레스테롤, $\mathrm{LDL}$-콜레스테롤 및 중성지방을 감 소시키는 기전과 관여 성분에 대해서는 앞으로 많은 추가 연구 가 이루어져야 할 것으로 사료된다.

혈청의 알부민, 크레아티닌, 요산, 포도당 및 총단백질의 적 정 농도는 체내의 정상적인 대사 활동을 보여주는 생화학적 지 표이다. $\mathrm{NC}$ 군, $\mathrm{HFC}$ 군 및 $\mathrm{HFC}+\mathrm{HE}$ 군 혈청의 농도를 분석한 결
과 $\mathrm{HFC}+\mathrm{HE}$ 군의 혈청 알부민, 크레아티닌, 요산, 포도당, 총단 백질 농도는 $\mathrm{NC}$ 군과는 모든 지표가 유사하게 측정되었으며, $\mathrm{HFC}$ 군에 비해 모든 수치가 유의하게 낮았다. 따라서 고지방 콜레스테롤 식이에 노루궁뎅이버섯 자실체가 첨가된 식이를 급 여한 흰쥐는 고지방 - 콜레스테롤 식이의 섭취로 인해 높아진 흰쥐 혈청의 생화학적 지표를 정상적인 수준으로 낮추어 정상 적인 상태로 조절할 수 있는 것으로 보인다.

간에 있는 AST, ALT 및 ALP는 주로 간에서 합성되며, 간이 손 상되면 혈액 중으로 유리되어, 이들 효소의 농도가 증가하게 된 다[30]. 혈액 내에 이러한 효소가 증가하는 것은 주로 간의 염증 이나간경화 등의 질환이 있을 때 증가하며 종양이 발생할 경우 에도 나타난다. ALP는 체내의 인산에스터를 분리시키고 장내 에서는 인의 흡수 등에 관여하는 효소로 골 질환, 간질환 및 악성 종양 등이 발생하면 활성이 증가한다[31,32]. 본 실험에서 AST, ALT, ALP효소의 활성을 조사한 결과 노루궁뎅이버섯 자실체 분말을 급여한 $\mathrm{HFC}+\mathrm{HE}$ 군의 효소 활성은 정상 식이군인 $\mathrm{NC}$ 군 과 매우 유사한 수준의 효소 활성을 보였으나 $\mathrm{HFC}$ 군에 비해 유 의하게 낮았다. 고지방 식이에 상황버섯 자실체 분말 $5 \%$ 를 첨가 한 식이를 흰쥐에 8주간 섭취시킨 후 혈액의 AST와 ALT 농도를 측정한 결과 상황버섯 첨가군이 고지방 식이만을 섭취한 군에 비해 AST와 ALT의 농도가 모두 감소하였으며 ALT농도는 고지 방 식이에 비해 통계적으로 유의하게 감소하였다[33]. 따라서 본 실험에서 고지방 - 콜레스테롤 식이에 첨가된 노루궁뎅이버 섯 자실체는 고지방 - 콜레스테롤 식이에 비해 흰쥐의 간 기능 손상 지표가 되는 효소 농도를 현저히 감소시켜 흰쥐의 간 대사 를 정상으로 유지해 간 손상을 보호하는 효과가 있는 것으로 사 료된다.

흰쥐가 변으로 배설한 $\mathrm{g}$ 당 총지질과 총콜레스테롤의 양은 정 상 식이군이나 고지방 - 콜레스테롤 식이군에 비해 노루궁뎅이 버섯 첨가군에서 각각 유의하게 증가하였다. 이러한 결과는 $1 \%$ 콜레스테롤 식이에 $5 \%$ 의 느타리버섯 자실체 분말을 첨가하여 6주 사육한 흰쥐가 배설한 총지질과 총콜레스테롤의 양이 정상 식이군과 콜레스테롤군보다 유의하게 높았다는 보고와 유사하 였다[34]. 따라서 본 실험에서 노루궁뎅이버섯 첨가군 변의 지 질과 콜레스테롤 배설량이 크게 증가한 것은 자실체에 함유된 주요 성분인 섬유소와 다당류가 지질의 소화와 흡수를 장에서 억제한 것에 기인한다고 사료된다.

정상식이, 고지방 - 콜레스테롤 식이, 그리고 고지방 - 콜레 스테롤 식이에 노루궁뎅이버섯 자실체를 첨가한 식이를 흰쥐에 6주간 급여하고 간을 적출하여 oil red O로 염색하여 식이 섭취 의 차이에 따른 간의 조직학적 변화를 광학현미경을 이용해 관 
찰하였다. 흰쥐에 고지혈증을 유발하게 되면 간세포에 지방질 의 축적이나 세포질의 위축 등 조직학적인 변화가 발생한다 [35]. 본 연구에서도 $\mathrm{HFC}$ 군의 세포사이에 다량의 지방질축적 이 관찰되었으나 $\mathrm{NC}$ 군의 간에는 지방질축적이나 세포질의 위 축이 보이지 않았다. $\mathrm{HFC}+\mathrm{HE}$ 군은 간세포질의 위축 등의 조직 학적 변화는 관찰되지 않았으나 간세포에 소량의 지방질축적이 관찰되었다. 따라서 $\mathrm{HFC}$ 군의 간과 달리 $\mathrm{HFC}+\mathrm{HE}$ 군의 간에 지 방질이 소량 축적된 것은 노루궁뎅이버섯의 자실체에 함유된 여러 성분이 간세포의 지방질축적을 크게 억제했기 때문으로 사료된다.

\section{요 약}

노루궁뎅이버섯의 자실체가 고지방과 콜레스테롤을 급여한 Sprague Dawley계 암컷 흰쥐의 지질대사와 생리활성에 미치 는 영향을 조사하고자 생후 5 주령의 흰쥐에 표준 식이를 급여한 정상군(NC군), 표준 식이에 $15 \%$ 의 돈지와 $1 \%$ 의 콜레스테롤을 첨가한 식이를 급여한 고지방 - 콜레스테롤군( $\mathrm{HFC}$ 군), 고지방 · 콜레스테롤 식이에 노루궁뎅이버섯 자실체 분말을 $5 \%$ 첨가한 군(HFC+HE군) 등 총 3개의 군으로 나누어 6주간 실험을 진행 하였다. 실험동물의 체중증가와 식이효율은 $\mathrm{HFC}$ 군에 비해 $\mathrm{HFC}+\mathrm{HE}$ 군이 유의하게 감소하여 $\mathrm{NC}$ 군과 유사한 수준을 나타 냈다. 식이섭취량은 $\mathrm{NC}$ 군과 $\mathrm{HFC}$ 군에 비해 $\mathrm{HFC}+\mathrm{HE}$ 군이 유의 하게 낮았다. $\mathrm{HFC}+\mathrm{HE}$ 군의 혈청 총콜레스테롤, $\mathrm{LDL}$-콜레스테 롤의 농도는 $\mathrm{NC}$ 군과 $\mathrm{HFC}$ 군에 비해 유의하게 낮았고 동맥경화 지수(AI)도 $\mathrm{NC}$ 군과 $\mathrm{HFC}$ 군에 비해 유의성 있게 낮았다. 그러나 혈청의 중성지방 농도는 $\mathrm{NC}$ 군에 비해 유의성은 없었으나 $\mathrm{HFC}$ 군에 비해 유의하게 낮았다. $\mathrm{HFC}+\mathrm{HE}$ 의 혈청 알부민, 크레아티 닌, 요산 및 총단백질의 농도는 $\mathrm{NC}$ 군의 수준을 나타냈다. 혈청 의 AST, ALT 및 ALP 활성은 NC군과 유사하였으나 $\mathrm{HFC}$ 군에 비 해 유의하게 낮았다. 실험 5 6주에 배출된 변을 채취하여 총지 질과 총콜레스테롤의 양을 분석한 결과 $\mathrm{NC}$ 군과 $\mathrm{HFC}$ 군에 비해 변의 총지질과 총콜레스테롤 함량이 유의하게 높아 변으로 배 출된 총지질과 총콜레스테롤의 양이 많게 증가한 것으로 나타 났다. 따라서 고지방 - 콜레스테롤식이에 $5 \%$ 의 노루궁뎅이버 섯 자실체 분말을 첨가한 식이를 급여한 흰쥐의 체중은 정상군 의 수준을 유지하였고, 혈청의 총콜레스테롤, LDL-콜레스테롤 및 중성지질의 농도도 정상군과 유사하게 낮았으며, 동맥경화 지수도 낮아 노루궁뎅이버섯이 흰쥐의 지질대사를 정상으로 유 지시키는 효과를 나타내는 것으로 사료되었다.

\section{Acknowledgements: None \\ Funding: None \\ Conflict of interest: None}

\section{REFERENCES}

1. Moon SJ. Nutrition problems of Koreans. Korean J Nutr. 1996; 29(4):371-380.

2. Jang SJ, Park YJ. Effects of dietary fiber sources and levels on lipid metabolism in rats fed high lard diet. Korean J Nutr. 1995;28(2):107-114.

3. Spady DK, Woollett LA, Dietschy JM. Regulation of plasma LDL-cholesterol levels by dietary cholesterol and fatty acids. Annu Rev Nutr. 1993;13(1):355-381.

4. Yao F, MacKenzie RG. Obesity drug update: The lost decade? Pharmaceut. 2010;3(12):3494-3521.

5. Molitoris HP. Mushrooms in medicine. Folia Microbiol 1994; 39(2):91-98.

6. Wasser SP. Medicinal mushrooms as a source of antitumor and immunomodulating polysaccharides. Appl Microbiol Biotechnol. 2002;60(3):258-274.

7. Yoon KN, Jang HS, Jin GH. Antioxidant, anti-diabetic, anti-cholinesterase, and nitric oxide inhibitory activities of fruiting bodies of Agaricus brasiliensis. Korean J Clin Lab Sci. 2015; 47(4):194-202.

8. Yoon KN, Jang HS. Antioxidant and antimicrobial activities of fruiting bodies of Phellinus gilvus collected in Korea. Korean J Clin Lab Sci. 2016;48(4):355-364.

9. Ahn DK. Medicinal fungi in Korea. Korean J Mycol. 1992; 20(2):154-166.

10. Park, WH. Lee, HD. Illustrated book of Korean medicinal mushrooms. Seoul: KyoHak; 2003. p442-443.

11. Ying JZ, Mao XL, et al. Icones of medicinal fungi. Beijing: Science Press; 1987. p90-91.

12. Kim DH, Park SR, Debnath T, Hasnat A, Pervin M, Lim BO. Evaluation of the antioxidant activity and anti-inflammatory effect of Hericium erinaceus water extracts. Korean J Medicinal Crop Sci. 2013;21(2):112-117.

13. Mizuno T, Wasa T, Ito H, Suzuki C, Ukai N. Antitumor active polysaccharides isolated from the fruiting body of Hericium erinaceum, an edible and medicinal mushroom called yamabushitake or houtou. Biosci Biotechnol Biochem. 1992;56(2):347348.

14. Kawagishi H, Shimada A, Hosokawa S, Mori H, Sakamoto H, Ishiguro Y, et al. Erinacines E, F and G stimulators of nerve growth factor synthesis from the mycelia of Hericium erinaceum. Tetrahedron Lett. 1996;37(41):7399-7402.

15. Reeves PG, Nielsen FH, Fahey GC Jr. AIN-93 purified diets for laboratory rodents: final report of the American institute of Nutrition ad hoc writing committee on the reformulation of the AIN-76A rodent diet. J Nutr. 1993;123(11):1939-1951.

16. Alam N, Yoon KN, Lee TS, Lee UY. Hypolipidemic activities of dietary Pleurotus ostreatus in hypercholesterolemic rats. Mycobiol. 2011;39(1):45-51.

17. Haglund O, Loustarinen R, Wallin R, Wibell I, Saldeen T. The ef- 
fect of fish oil on triglycerides, cholesterol, fibrinogen and malondialdehyde in humans supplemented with vitamin E. Eur J Nutr. 1991;121(2):165-169.

18. Kobayashi H, Matsushita M, Oda K, Nishikimi N, Sakuri T, Komori K. Effects of atherosclerotic plaque on the enlargement of an experimental model of abdominal aortic aneurysm in rabbits. Eur J Vasc Endovasc Surg. 2004;28(1):71-78.

19. Folch J, Lees M, Sloane Stanley GH. A simple method for the isolation and purification of total lipids from animal tissues. J Biol Chem 1957;226(1):497-509.

20. Oh SW, Lee CU, Koh JB. Effects of Agaricus blazei Murill on lipid metabolism in rats fed high fat diet. J Korean Soc Food Sci Nutr. 2004;33(5):821-826.

21. Koh JB, Choi MA. The effects of Cordyceps militaris on lipid metabolism in rats fed cholesterol diet. Korean J Nutr. 2001;34(3):265-270.

22. Park SY, Bae IY, Lee S, Lee HG. Physicochemical and hypocholesterolemic characterization of oxidized oat beta glucan. J Agric Food Chem. 2009;57(2):439-443.

23. Bisen PS, Baghel RK, Sanodiya BS, Thakur GS, Prasad GB. Lentinus edodes: a macrofungus with pharmacological activities. Curr Med Chem. 2010;17(22):2419-2430.

24. Ross R. The pathogenesis of atherosclerosis: a perspective for the 1990s. Nature. 1993;362(6423):801-809.

25. Koh JB. The effects of Cordyceps militaris on lipid metabolism, protein levels and enzyme activities in rats fed a high fat diet. Korean J Nutr. 2002;35(4):414-420.

26. Bobek P, Ginter E, Kuniak L, Babala J, Jurcovicova M, Ozdin L, Cerven J. Effect of mushroom Pleurotus ostreatus and isolated fungal polysaccharide on serum and liver lipids in Syrian hamsters with hyperlipoproteinemia. Nutr. 1991;7(2):105-108.

27. Koh JB, Choi MA. Effect of Pacilomyces japonica on lipid metabolism in rats fed high fat diet. J Korean Soc Food Sci Nutr.
2003;32(2):238-243.

28. Cheung PCK. The hypercholesterolemic effect of two edible mushrooms: Auricularia auricula (tree-ear) and Tremella fuciformis (white jelly-leaf) in hypercholesterolemic rats. Nutr Res. 1996;16(10):1721-1725.

29. Agah HM, Alipour A, Janbozorgi M, Hajihosseini R, Shaghaghi, F, Golchin N, Nouhi S. Lipid profile improvement after four group psychological interventions in combination to nutritional and physical activity instructing among overweight and obese individuals. Iran J Public Health. 2013;42(1):86-95.

30. Qu L, Xin H, Zheng G, Su Y, Ling C. Hepatoprotective activity of the total saponin from Actinidia valvata Dunn root against carbon tetrachloride-induced liver damage in mice. Evid-Based Complement Alternat Med. 2012;2012:216061

31. Ma X, Li Z. Pathogenesis of nonalcoholic steatohepatitis (NASH). Chin J Dig Dis. 2006;7(1):7-11.

32. Zou Y, Li J, Lu C, Wang J, Ge j, Huang Y, et al. High-fat emulsion induced rat model of nonalcoholic steatohepatitis. Life Sci. 2006;79(11):1100-1107.

33. Kim JH, Son IS, Kim JS, Kim KH, Kwon CS. Lipase-inhibitory and anti-oxidative activity of the methanol extract and the powder of Phellinus linteus. J Korean Soc Food Sci Nutr. 2008;37(2):154-161.

34. Yoon KN, Alam N, Shim MJ, Lee TS. Hypolipidemic and antiatherogenesis effect of culinary-medicinal pink oyster mushroom, Pleurotus salmoneostramineus L. Vass. (Higher Basidiomycetes), in hypercholesterolemic rats. Int J Med Mushrooms. 2012;14(1):27-36.

35. Kim GY, Jung HW, Kim EJ. Anti-hyperlipidemic effect of shiitake mushroom extract in hyperlipidemic rats induced by poloxamer-407. Korean J Orient Physiol Pathol. 2013;27(4); 409-415. 